\title{
Influence of carbon availability on denitrification in the central Baltic Sea
}

\section{Ingrid Brettar ${ }^{1}$ and Gerhard Rheinheimer}

Institut für Meereskunde an der Universität Kicl, Düsternbrooker Weg 20, D-2300 Kiel, Germany

\begin{abstract}
Denitrification was investigated in the Baltic proper at two stations with different conditions in the deep water. The Gotland Deep was examined as an example of a basin with anoxic, $\mathrm{H}_{2} \mathrm{~S}$ containing dcep water and station $T$ was taken as an example of low-oxygen $\left(<0.2 \mathrm{ml}\right.$ liter $\left.{ }^{1}\right)$, sulfide-free deep water. Denitrification was measured by the acetylene blockage method; in addition, $\mathrm{N}_{2} \mathrm{O}$ reduction was followed in samples without acetylene. To shed light on the factors limiting denitrification, we compared in situ rates to denitrification after adding nitrate or electron donors. Denitrification was restricted to the layer of the oxic-anoxic interface in the Gotland Deep and to the water layer near the sediment of station $T$. For both stations it could be shown that denitrification was not limited by nitrate availability. A lack of available organic $\mathrm{C}$ scemed to limit denitrification rates and growth of denitrifiers. As a result of $\mathrm{C}$ limitation in the water column, denitrification was restricted to energy-rich interfaces. In the low-oxygen water away from energyrich interfaces, the less C-demanding nitrification-denitrification coupling $\left(\mathrm{NH}_{4}{ }^{r} \rightarrow \mathrm{N}_{2} \mathrm{O} \rightarrow \mathrm{N}_{2}\right.$ ) seemed to be favored. Denitrification in the water of the central Baltic secms to be subjected to strong variability due to changing $C$ supply during the course of the year. However, limitation by $\mathrm{C}$ availability can be assumed for most of the year and should be taken into account in calculating the $\mathrm{N}$ budget of the Baltic.
\end{abstract}

The Baltic Sca as a whole can be described as a big estuary. The Baltic proper represents the largest and southernmost part of it. The Baltic Sea is strongly influenced by human activity insofar as loads of $\mathrm{N}$ and $\mathrm{P}$ are concerned (Elmgren 1989). The Baltic proper is an ecosystem whose primary production is controlled by $\mathrm{N}$ availability (Wulff and Rahm 1988; Graneli et al. 1990). Denitrification, defined as the bacterially mediated process of dissimilatory reduction of ionic nitrogen oxides $\left(\mathrm{NO}_{3}{ }^{-}\right.$and $\left.\mathrm{NO}_{2}{ }^{-}\right)$to gaseous nitrogen compounds $\left(\mathrm{NO}, \mathrm{N}_{2} \mathrm{O}\right.$, and $\mathrm{N}_{2}$ ), can be regarded as a major process of elimination of available N (Goering 1985). Thus, denitrification is an important process in counteracting eutrophication (Rönner 1985).

The Baltic proper is characterized by a permanent halocline $(60-90 \mathrm{~m})$ that inhibits

' Current address: NIWAR, Water Quality Centre, P.O. Box 11-115, Hamilton, New Zealand.

Acknowledgments

Assistance during the cruises by J. Wesnigk and R. Lilischkis and the support by the crews of RV Aranda and RV Poseidon are acknowledged. We thank E. L. Poutanen for support on the cruise in 1987.

The project was financed by the Bundesministerium für Forschung und Technologie (project MFU 0547-1). seasonal vertical mixing deeper than $70 \mathrm{~m}$. The rencwal of water masses below the halocline relies on horizontal exchange processes that are discontinuous and, especially below $130 \mathrm{~m}$, rare events. Stagnation periods between deep-water renewal may last up to $10 \mathrm{yr}$, as was the case before our investigation. During these stagnation periods, oxygen level decreases in the water masses below the halocline and, especially in basins like the Gotland Deep, $\mathrm{H}_{2} \mathrm{~S}$ from the sediment accumulates in the deep water (Stigebrandt and Wulff 1987).

This investigation was aimed at understanding the factors limiting denitrification in the central Baltic. It is generally accepted that oxygen concentration, the availability of organic $\mathrm{C}$ (as electron donor), and $\mathrm{NO}_{3}{ }^{-}$ (as electron acceptor) are the most important factors controlling the occurrence and rate of denitrification (Hattori 1983). Although $\mathrm{NO}_{3}{ }^{-}$and the more reduced nitrogen oxides can all serve as electron acceptors for denitrification, it is assumed that $\mathrm{NO}_{3}{ }^{-}$ is preferred to the more reduced intermediates of the denitrification path (Goering 1985). The importance of the availability of organic $\mathrm{C}$ for the rate of denitrification was pointed out by Liu and Kaplan (1984), who 
showed a strong correlation between the flux of organic particles derived from phytoplankton primary production that reach the denitrification layer and denitrification rates observed in the respective marine ecosystems.

The first investigations of denitrification in the Baltic were done by Rönner and Sörensson (1985) in the western part of the Baltic proper. According to their measurements made in late spring 1980 , denitrification seemed to be limited by the availability of $\mathrm{NO}_{3}{ }^{-}$and occurred when the oxygen concentration fell below $0.2 \mathrm{ml} \mathrm{li}$ $\operatorname{ter}^{-1}$. Comparable or lower oxygen values for the onset of denitrification have been reported by many others (see Goering 1985).

Our aim was to take a closer look at the factors regulating denitrification in the central Baltic. Emphasis was put on the interaction between electron donor availability and denitrification. For this purpose, two sampling stations were selected that are considered to be representative of the Baltic proper. As shown by Wulff and Rahm (1989), the Gotland Deep (also called station BY 15) is believed to be the most representative station of the Baltic proper; station $T$ is very close to BY 28 , which Wulff and Rahm claimed to be representative for the northern part of the Baltic proper. The Gotland Deep was investigated as an example of denitrification in a water column with sulfide-containing deep water and station $T$ as an example of a low oxygen, sulfide-free water column. The period of investigation (midsummer) was more representative of the year's average at least as far as the supply of organic $\mathrm{C}$ is concerned (Stigebrandt and Wulff 1987).

To answer the above questions, we locatcd the denitrification zone and determined the in situ rates. These in situ rates were compared to denitrification after addition of $\mathrm{NO}_{3}{ }^{-}$and possible electron donors. The acetylene inhibition method was used to quantify denitrification rates. Additionally, reduction of $\mathrm{N}_{2} \mathrm{O}$ to $\mathrm{N}_{2}$ was followed by recording the disappearance of $\mathrm{N}_{2} \mathrm{O}$ in samples without acetylene addition. To estimate the organic $\mathrm{C}$ available for denitrification, we followed degradation of particulate organic $\mathrm{C}$ (POC) and change of

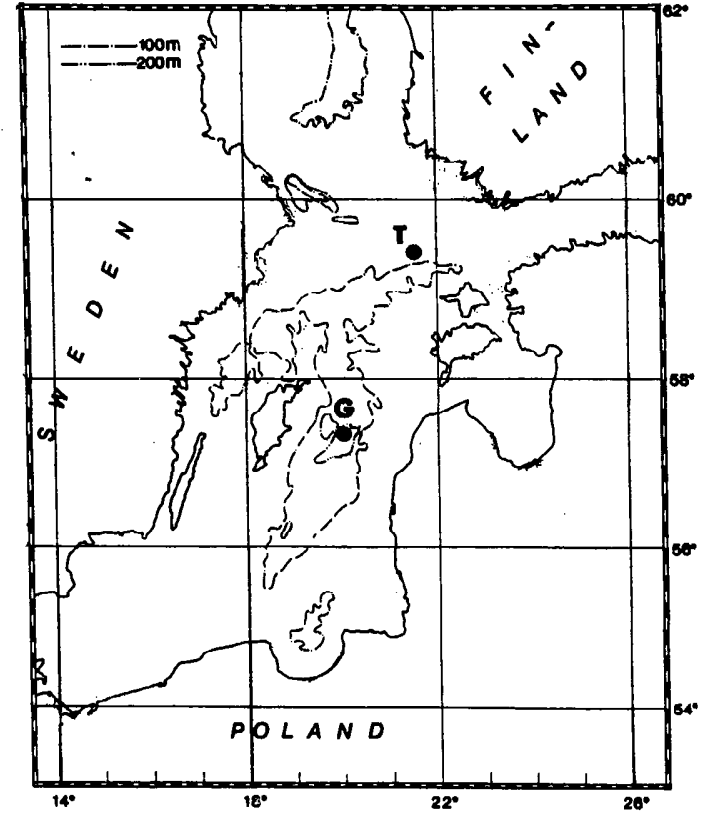

Fig. 1. Positions of the sampling stations in the Baltic proper. G-Gotland Deep; $\mathrm{T}$-station $\mathrm{T}$.

the nitrogenous compounds during a $100-d$ incubation period. We also followed microbiological background parameters, total bacterial numbers, and the number of denitrifying bacteria as detected by $\mathrm{N}_{2} \mathrm{O}$ production and $\mathrm{N}_{2}$ formation.

\section{Material and methods}

Sampling and field measurements-Samples were taken aboard RV Poseidon from 15 to 19 August 1986 and aboard RV $A r$ anda from 29 to 31 July 1987 in the Gotland Deep (=BY 15) and at station T (close to BY 28). Positions of the Gotland Deep $\left(57^{\circ} 20.0^{\prime} \mathrm{N}, 20^{\circ} 03.0^{\prime} \mathrm{E}\right)$ and of station $\mathrm{T}$ $\left(59^{\circ} 25.0^{\prime} \mathrm{N}, 21^{\circ} 30.0^{\prime} \mathrm{E}\right)$ are shown in Fig. 1. Water was collected in 5-, 10-, and 30-liter Niskin PVC bottles for all purposes, except for samples used to count saprophytes and denitrifying bacteria. For the latter, sterile champagne bottles mounted on modified ZoBell samplers were used. Salinity and temperature was determined by a CTD probe. Oxygen was measured by the Winkler method as described by Grasshoff(1983). $\mathrm{NH}_{4}{ }^{+}$was determined by the indophenol blue method as modified by Koroleff (1983). 
$\mathrm{NO}_{3}^{-}$was reduced by a $\mathrm{Cu}-\mathrm{Cd}$ column to $\mathrm{NO}_{2}{ }^{-}$and determined as $\mathrm{NO}_{2}{ }^{-}$as outlined by Grasshoff (1983). $\mathrm{H}_{2} \mathrm{~S}$ was determined photometrically by the methylene blue method as modified by Fonselius (1983). The above methods are specified in "Methods of seawater analysis" (Grasshoff et al. 1983). The parameters were analyzed by the scientific crew of the respective ships directly after sampling.

Determination of denitrification rateRates of denitrification were determined by the acetylene blockage method (Balderston et al. 1976; Yoshinari and Knowles 1976). The method used was a modification of those described by Rönner and Sörensson (1985) and Andersen et al. (1984). Samples were filled in $120-\mathrm{ml}$ glass serum bottles directly after sampling, with overflowing to reduce oxygen contamination. Bottles were closed immediately with a Teflon-coated butyl rubber septum $(3 \mathrm{~mm})$ in an aluminum cap and crimped. This procedure allowed air-bubble-free and airtight containment of the sample. To create space to introduce acetylene to the sample, we replaced $10 \mathrm{ml}$ of water by the same volume of nitrogen $\left(\mathrm{N}_{2}, 5.0 \mathrm{ml}\right)$. We added $18 \mathrm{ml}$ of acetylene $\left[\mathrm{C}_{2} \mathrm{H}_{2}(2.6 \mathrm{ml})\right.$ in cylinder, purified and controlled for $\mathrm{PH}_{3}<5 \mathrm{ppm}$ by the manufacturer] to each sample. Acetylene was added directly to the water phase with a syringe after inverting the bottle. Solution of acetylene was accelerated by vigorous shaking during and after acetylene addition. We had a final concentration of $15 \%$ acetylene in the water sample. An increased acetylene concentration of $15 \%$ compared to $10 \%$ used by other investigators (e.g. Rönner and Sörensson 1985) was done to ensure inhibition of $\mathrm{N}_{2} \mathrm{O}$ reduction even in the presence of $\mathrm{H}_{2} \mathrm{~S}$, which was of special relevance at the oxic-anoxic interfaces (Brettar and Rheinheimer 1991). We did not observe any influence of this increased acetylene addition on any of the processes followed during incubation of the samples. Gases were supplied by Messer-Griesheim. Samples were incubated at $4.8 \pm 0.5^{\circ} \mathrm{C}$ in the dark for 2, 4, 6, and $12 \mathrm{~d}$. Addition of substrates $\left(\mathrm{NO}_{3}{ }^{-}, \mathrm{Na}_{2} \mathrm{~S}, \mathrm{Na}_{2} \mathrm{~S}_{2} \mathrm{O}_{3}, \mathrm{Na}\right.$-acetate, glucose) was always done before introduc- tion of gases to the sample. For comparison, parallels were always run without added acetylene.

$\mathrm{N}_{2} \mathrm{O}$ measurement-For $\mathrm{N}_{2} \mathrm{O}$ measurements, we withdrew gas samples from the headspace by a gastight lockable syringe after equilibrating the sample for $15 \mathrm{~min}$ at $20^{\circ} \mathrm{C}$ in a shaking water bath. Samples were immediately frozen after this procedure and stored for later analysis (e.g. $\mathrm{NO}_{3}{ }^{-}, \mathrm{NO}_{2}{ }^{-}$, $\mathrm{NH}_{4}{ }^{+}$). Gas samples were either directly injected into a gas chromatograph or stored for later analysis in evacuated vials (4-ml Vacutainer, Becton Dickinson). $\mathrm{N}_{2} \mathrm{O}$ concentrations were quantified on a gas chromatograph (model 438A, Packard Instr. Co., Inc.) with an electron capture detector (10 $\mathrm{mCi}{ }^{63} \mathrm{Ni}$ ) operated at $320^{\circ} \mathrm{C}$. Separation was done by injecting $1 \mathrm{ml}$ of the gas sample on a stainless steel Poropak Q (80/100 mesh) column $(3 \mathrm{~m})$, at $60^{\circ} \mathrm{C}$ and a gas flow of 18

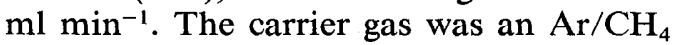
(95:5, vol/vol) mixture.

The standard deviation for $\mathrm{N}_{2} \mathrm{O}$ determinations after storage of the samples in evacuated vials was better than $2 \%$ for concentrations $>30 \mathrm{nmol}$ liter $^{-1}$, better than $5 \%$ above $10 \mathrm{nmol}$ liter $^{-1}$, and better than $9 \%$ above $5 \mathrm{nmol}$ liter $^{-1}$. The detection limit was 3 nmol liter ${ }^{-1}$. The $\mathrm{N}_{2} \mathrm{O}$ measurements were calibrated against standard $\mathrm{N}_{2} \mathrm{O}$ mixtures provided by Messer-Griesheim and Alltech Europe. These gases were compared to standards provided by the Frauenhofer Institut für atmosphärische Umweltchemie. The $\mathrm{N}_{2} \mathrm{O}$ concentrations in the water were calculated according to Weiss and Price (1980). To calculate the saturation value in the water sample, we used a value of 300 ppbv $\mathrm{N}_{2} \mathrm{O}$ as the mean air value according to the mean air concentration close to the surface of the Baltic as determined by Rönner (1983a).

Bacterial parameters-Total counts of bacteria were done under an epifluorescence microscope after staining with acridine orange according to Zimmermann et al. (1978). All samples were fixed in $2 \%$ formaldehyde.

Saprophytes were grown aerobically on yeast extract-peptone agar medium ZoBell 2216E (Oppenheimer and ZoBell 1952) prepared with natural seawater diluted to $8 \%$ 
salinity. Colony-forming units (CFU) were counted after incubation for $14 \mathrm{~d}$ in the dark at $20^{\circ} \mathrm{C}$.

Denitrifying bacteria were grown in a nutrient-broth-nitrate medium modified from Sreenivasan and Venkatarman (1956); it had the following composition: meat extract (Merck), $3.0 \mathrm{~g}$; Bacto-peptone (Difco), 5.0 g; $\mathrm{KNO}_{3}, 2.0 \mathrm{~g}$; aged seawater, $250 \mathrm{ml}$; deionized water, $750 \mathrm{ml}$; pH $7.35 \pm 0.05$. The medium was filled into Hungate tubes; Durham tubes were added to observe gas formation. The inoculum ranged from 0.001 to $10 \mathrm{ml}$, achieved in three parallels in 1986 and five parallels in 1987. Tubes were incubated for 5 weeks in the dark at $20^{\circ} \mathrm{C}$. As a criterion for denitrifiers, gas formation in the Durham tubes was observed and $\mathrm{N}_{2} \mathrm{O}$ in the headspace was measured gas chromatographically. Gas formation was attributed (most likely) to $\mathrm{N}_{2}$ production, as $\mathrm{CO}_{2}$ production was quantified concomitantly. Sampling of gases in the headspace was done after shaking and equilibration of the liquid medium with the gas phase. As gas sample $(1 \mathrm{ml})$ was analyzed for $\mathrm{N}_{2} \mathrm{O}$ and $\mathrm{CO}_{2}$ by the same method as described above for $\mathrm{N}_{2} \mathrm{O}$ measurement, but with a lower detector temperature of $300^{\circ} \mathrm{C}$ that decreased the detection limit for $\mathrm{CO}_{2}$ to $0.8 \% \mathrm{vol} / \mathrm{vol}$. There was no interference between the measurements of $\mathrm{CO}_{2}$ and $\mathrm{N}_{2} \mathrm{O}$ under the running conditions used. The concomitant measurement of $\mathrm{CO}_{2}$ enabled us to recognize gas production due to $\mathrm{CO}_{2}$ production. Data evaluation was done according to the MPN tables of de Man (1975).

Particulate organic $C-$ The POC content of water samples was determined after filtering 1 liter of water through a $25-\mathrm{mm}$ glassfiber filter (Whatman GF/F, precombusted at $450^{\circ} \mathrm{C}$ ). The sample was combusted at $960^{\circ} \mathrm{C}$ in a Perkin-Elmer CHN analyzer.

The change of the POC content was followed during a 100-d incubation of 1-liter samples (in 1-liter glass bottles, acid-rinsed, with screwcap equipped with Teflon-coated butyl rubber septum) after adding $500 \mu \mathrm{mol}$ liter ${ }^{-1} \mathrm{NaNO}_{3}$. Filling of the bottles and incubation was done as described for determination of in situ denitrification. Because no acetylene was added to the samples, de- nitrification was followed by measuring $\mathrm{NO}_{2}{ }^{-}, \mathrm{NO}_{3}{ }^{-}, \mathrm{NH}_{4}{ }^{+}$, and $\mathrm{N}_{2} \mathrm{O}$ concentrations.

This high amount of $\mathrm{NO}_{3}{ }^{-}$was added to compare our results to the findings of Rönner and Sörensson (1985), where a high percentage of the added $500 \mu \mathrm{mol}$ liter $^{-1}$ was reduced to $\mathrm{N}_{2}$ or $\mathrm{NO}_{2}{ }^{-}$during a 4-week incubation period. Furthermore, we wanted to make sure that $\mathrm{NO}_{3}^{-}$was not used up during the long incubation period, to enable a comparison of the amount of $\mathrm{NO}_{3}^{-}$reduced and the amount of POC consumed.

Statistical analyses-All calculations were done with the Statgraphics statistical graphics system (Statistical Graphics Corp.). All regressions (least-squares) were calculated with a 95\% confidence limit (=inner line shown in graphs, outer line $=95 \%$ prediction limits).

\section{Results}

In situ measurements - The depth profiles of physical, chemical, and microbiological parameters are summarized in Figs. 2 and 3. Profiles of the Gotland Deep obtained in 1986 and 1987 were quite similar and the one shown is typical for summer (Rheinheimer et al. 1989).

The water column was characterized by two density gradients: the thermocline at 20 $\mathrm{m}$ and the halocline at $60-90 \mathrm{~m}$. The thermocline formed the lower boundary of the layer of phytoplankton primary production (Gocke 1989).

At both stations, oxygen was close to saturation level $(>80 \%)$ in the water above the halocline. $\mathrm{O}_{2}$ decreased strongly in the halocline. Oxygen deficiency was met only in water samples of the Gotland Deep that contained $\mathrm{H}_{2} \mathrm{~S}$. Lowest $\mathrm{O}_{2}$ levels in water samples without $\mathrm{H}_{2} \mathrm{~S}$ were $>0.35 \mathrm{ml} \mathrm{liter}^{-1}$ in the Gotland Deep. In the Gotland Deep, $\mathrm{H}_{2} \mathrm{~S}$ concentrations increased from the oxicanoxic interface toward the sediment; in 1987 this increase was almost linear. The water of station $\mathrm{T}$ displayed a low oxygen layer from $100 \mathrm{~m}$ down to the sediment with oxygen concentrations from 0.20 to $0.09 \mathrm{ml}$ $\mathrm{O}_{2}$ liter $^{-1}$. $\mathrm{H}_{2} \mathrm{~S}$ could not be detected.

In general, $\mathrm{NO}_{3}{ }^{-}$was low in the upper 10 $\mathrm{m}$ and reached only low concentrations 

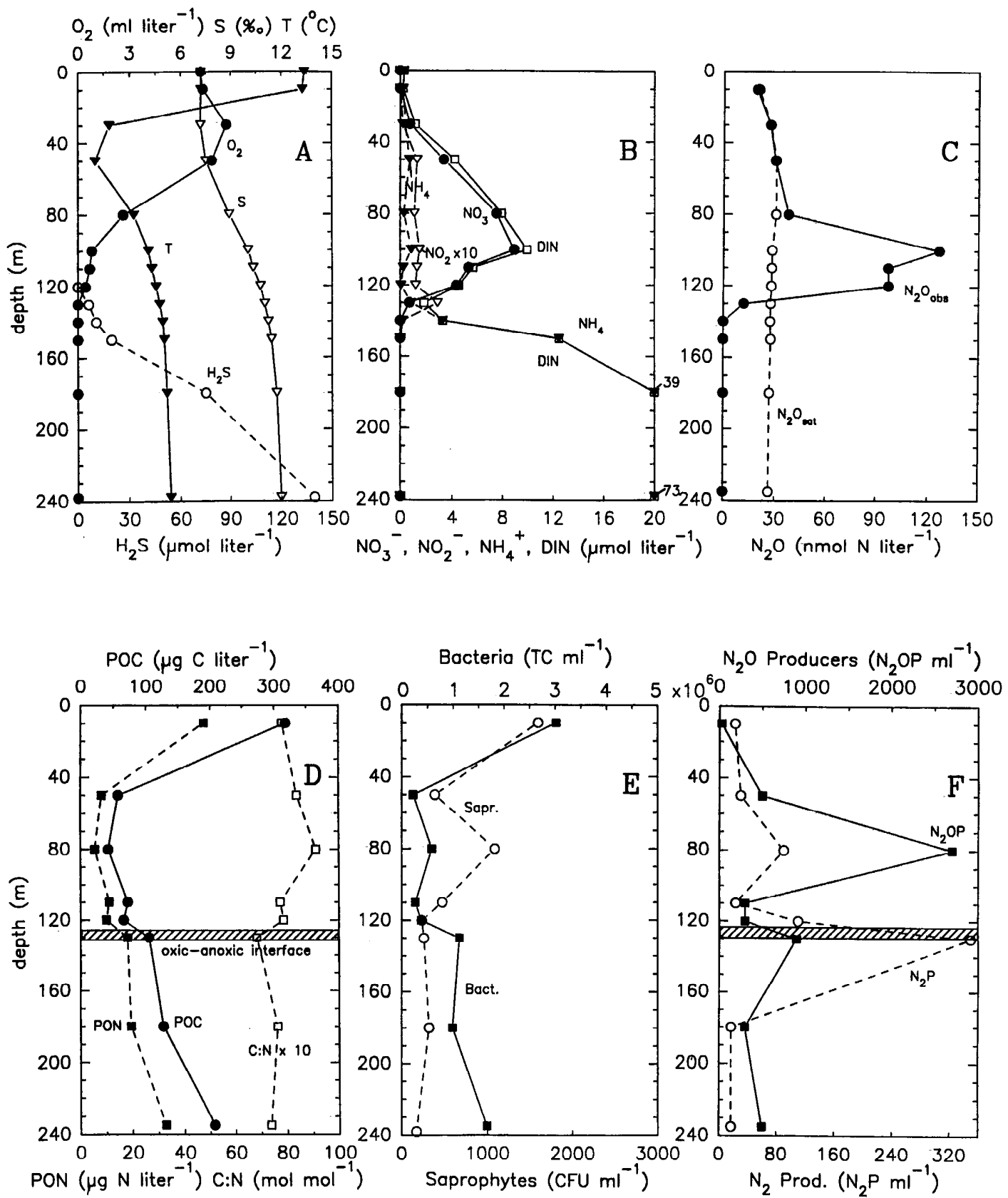

Fig. 2. Depth profiles of hydrographical, chemical, and microbiological parameters for the Gotland Deep, 29-31 July 1987. A. Oxygen, salinity, temperature, and $\mathrm{H}_{2} \mathrm{~S}$. B. Vertical distribution of $\mathrm{NO}_{3}{ }^{-}, \mathrm{NO}_{2}{ }^{-}, \mathrm{NH}_{4}{ }^{\circ}$, and DIN (=sum of $\left.\mathrm{NO}_{3}{ }^{-}+\mathrm{NO}_{2}{ }^{-}+\mathrm{NH}_{4}{ }^{+}\right)$. C. Observed $\mathrm{N}_{2} \mathrm{O}$ concentration $\left(\mathrm{N}_{2} \mathrm{O}_{\text {obs }}\right)$ and calculated saturation level $\left(\mathrm{N}_{2} \mathrm{O}_{3}\right)$. D. POC and PON distribution. E, F. Distribution of total bacterial numbers (TC), saprophytes, and denitrifying bacteria, detected as $\mathrm{N}_{2} \mathrm{O}$-producing $\left(\mathrm{N}_{2} \mathrm{OP}\right)$ and $\mathrm{N}_{2}$-producing bacteria $\left(\mathrm{N}_{2} \mathrm{P}\right)$. 

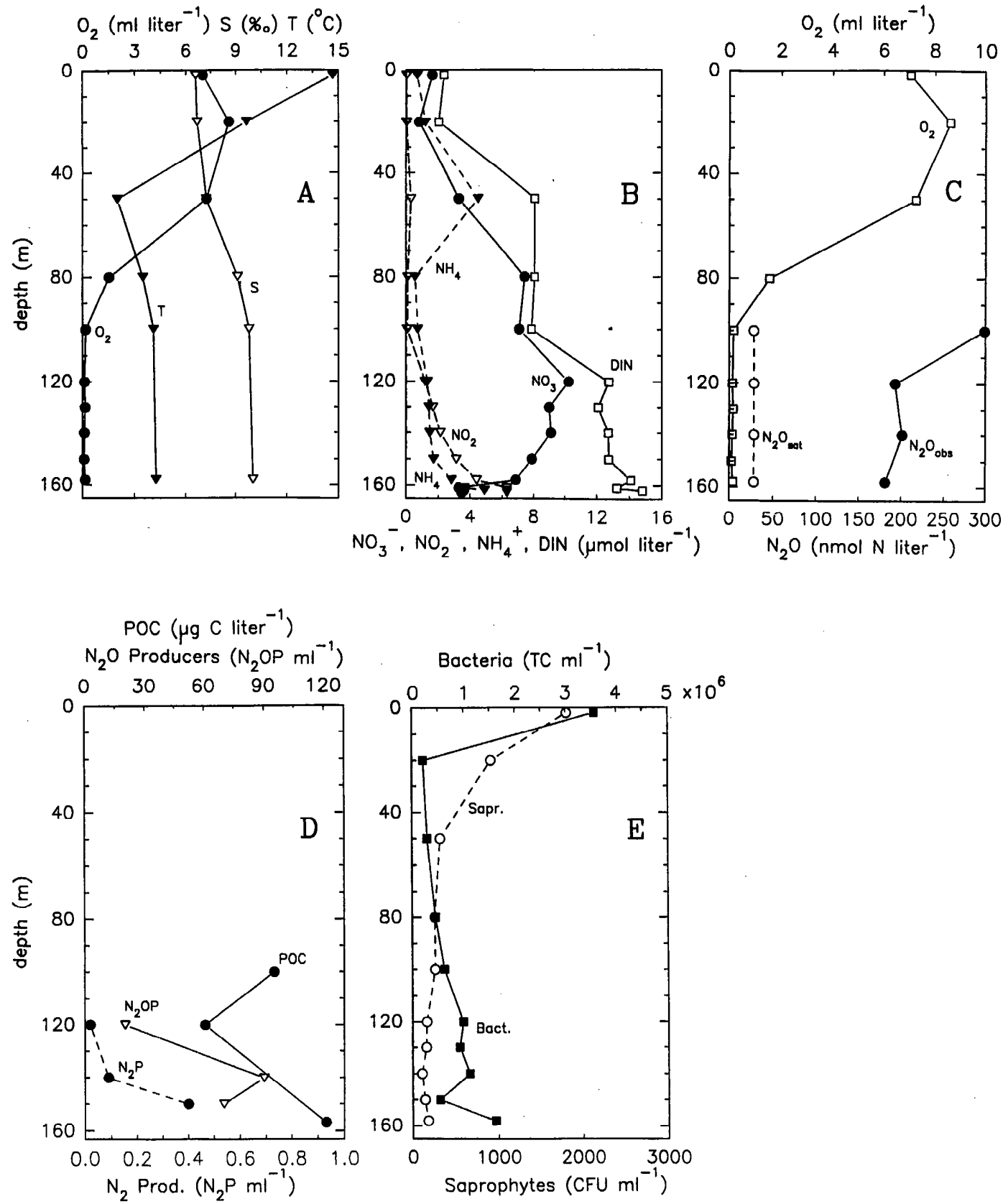

Fig. 3. As Fig. 2, but for station T, 19 August 1986.

above the halocline. Within and below the halocline $\mathrm{NO}_{3}{ }^{-}$increased up to $11 \mu \mathrm{mol} \mathrm{li-}$ $\operatorname{ter}^{-1}$. In the Gotland Deep, typically a pronounced peak was observed above the oxicanoxic interface, followed by a strong decline in the interface layer. In the water col- umn of both stations, $\mathrm{NO}_{3}{ }^{-}$concentrations were always highest in the water that was low in oxygen. In the Gotland Deep, low oxygen water showed with a significant decrease of $\mathrm{NO}_{3}{ }^{-}$above the $\mathrm{H}_{2} \mathrm{~S}$ layer. At the top of the $\mathrm{H}_{2} \mathrm{~S}$ layer concentrations of $\mathrm{NO}_{3}{ }^{-}$ 


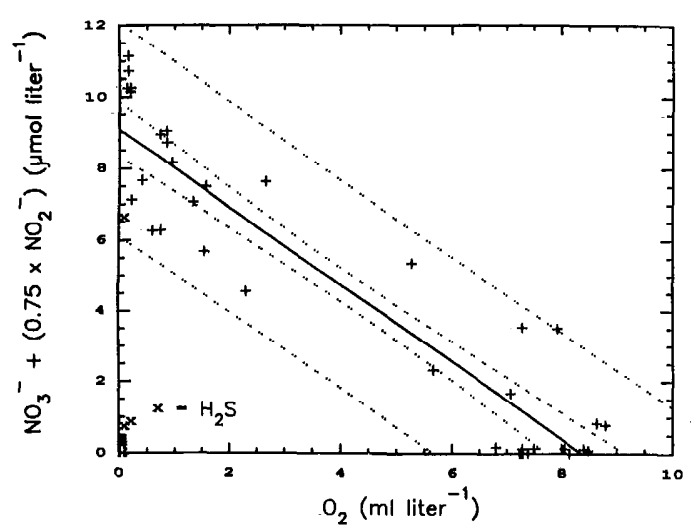

Fig. 4. Plot of oxygen vs. $\mathrm{NO}_{3}{ }^{-}+\left(0.75 \times \mathrm{NO}_{2}{ }^{-}\right)$. The linear regression for data from the Gotland Deep 1986 and 1987 and station $\mathrm{T}$ gave a correlation coefficient of $r=-0.937(a=9.09, b=1.086)$. In this calculation, values from samples with $\mathrm{H}_{2} \mathrm{~S}$ were omitted but their positions are indicated.

were very low in the presence of low concentrations of $\mathrm{H}_{2} \mathrm{~S}$. $\mathrm{NO}_{3}{ }^{-}$disappeared with increasing $\mathrm{H}_{2} \mathrm{~S}$ concentrations $(>10 \mu \mathrm{mol}$ liter $\left.{ }^{-1}\right)$ in the deeper part of the anoxic layer.

In the Gotland Deep $\mathrm{NO}_{2}{ }^{-}$showed only low concentrations. At station $\mathrm{T}$ there was a marked increase of $\mathrm{NO}_{2}{ }^{-}$in the layer of low oxygen water toward the sediment-up to $6.3 \mu \mathrm{mol} \mathrm{liter}^{-1}$ at $2 \mathrm{~m}$ above the sediment (samples taken with a bottom-water sampler).

The correlation between oxygen and the nitrification products $\mathrm{NO}_{3}{ }^{-}$and $\mathrm{NO}_{2}{ }^{-}$can be seen from the plot of $\mathrm{NO}_{3}^{-}+\mathrm{NO}_{2}^{-}$vs. $\mathrm{O}_{2}$ when data from both stations were used (Fig. 4). $\mathrm{NO}_{2}^{-}$was multiplied by the factor 0.75 because of the lower oxygen demand for oxidation of $\mathrm{NH}_{4}^{+}$to $\mathrm{NO}_{2}^{-}$compared to oxidation to $\mathrm{NO}_{3}{ }^{-}$.

Nitrification occurred in the low oxygen water as long as no $\mathrm{H}_{2} \mathrm{~S}$ was present. All samples from the low oxygen water of both stations showed increased $\mathrm{NO}_{3}{ }^{-}$concentrations during incubation. Additionally, samples from station $T$ showed a decrease of the endogenous $\mathrm{NO}_{2}{ }^{-}$concentration with a concomitant increase of $\mathrm{NO}_{3}{ }^{-}$concentration (data not shown).

The $\mathrm{NH}_{4}^{+}$concentrations were usually very low in the oxic part of the water column. Higher concentrations occasionally occurred below the euphotic zone and in the

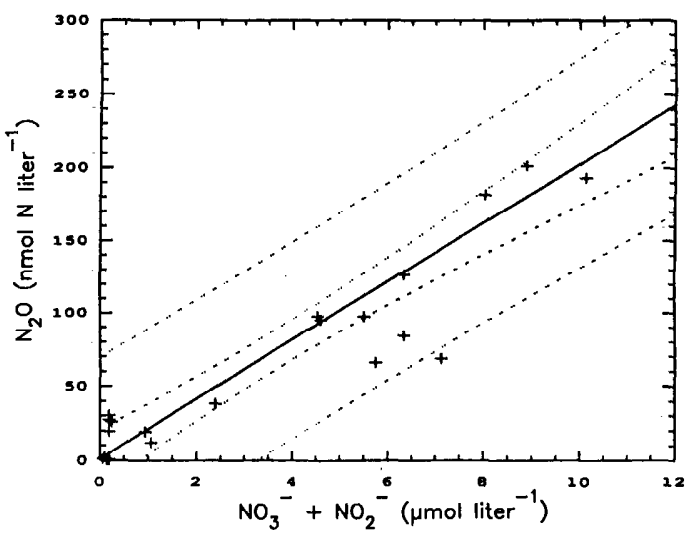

Fig. 5. Linear regression of $\mathrm{N}_{2} \mathrm{O}$ on $\mathrm{NO}_{3}+\mathrm{NO}_{2}$ $(r=0.923 ; a=1.19, b=20.159)$. Data source as in Fig. 4.

halocline. In the Gotland Deep high concentrations occurred in the anoxic part of the water column, where $\mathrm{NH}_{4}{ }^{+}$showed an increase similar to that of $\mathrm{H}_{2} \mathrm{~S}$ toward the sediment. A minor increase toward the sediment was also seen at station $\mathrm{T}$.

The sum of $\mathrm{NO}_{3}^{-}, \mathrm{NO}_{2}^{-}$, and $\mathrm{NH}_{4}{ }^{+}$that represents the major fraction of the dissolved inorganic $\mathrm{N}$ (DIN) showed a stepwise increase toward the sediment. In the Gotland Deep this increase was always interrupted by a pronounced minimum in the zone of the oxic-anoxic interface. Maximum concentrations were always observed above the sediment. In 1987, the Gotland Deep displayed much higher DIN concentrations above the sediment than those observed for both stations in 1986. DIN concentrations are given here as potential indicators for layers of pronounced nitrogen utilization (e.g. due to strong nitrogen assimilation in the euphotic layer or to denitrification).

$\mathrm{N}_{2} \mathrm{O}$ concentrations were close to the atmospheric saturation value in the water column above the halocline. Supersaturation was always found in the water of the lower part of the halocline and below the halocline. In the Gotland Deep maximum values of $\mathrm{N}_{2} \mathrm{O}$ saturation were $450 \%$ at $100 \mathrm{~m}$ in 1987 and $330 \%$ at $90 \mathrm{~m}$ in $1986 . \mathrm{N}_{2} \mathrm{O}$ decreased to $43 \%$ (1987) and $70 \%$ (1986) of saturation at the oxic-anoxic interface and was depleted in the anoxic deep water. At 


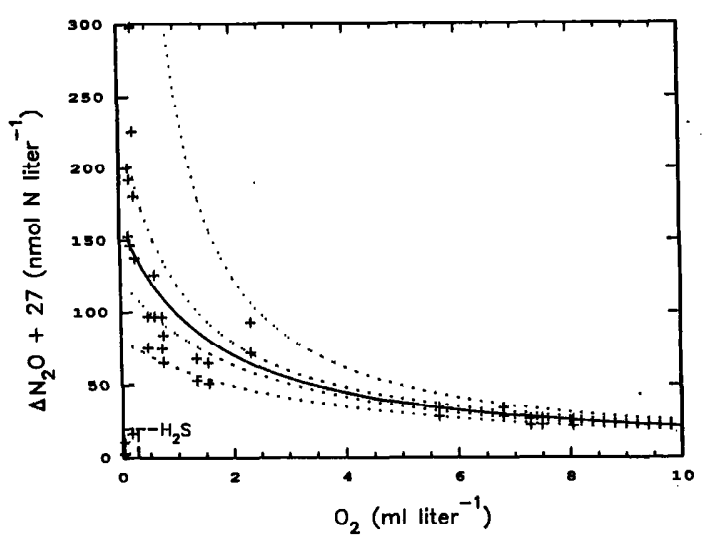

Fig. 6. Reciprocal regression of $\Delta \mathrm{N}_{2} \mathrm{O}$ (=measured value minus calculated saturation value) on $\mathrm{O}_{2}$. For the regression shown, $27 \mathrm{nmol} \mathrm{N}_{2} \mathrm{O}-\mathrm{N}$ liter $^{-1}$ was added to all $\Delta \mathrm{N}_{2} \mathrm{O}$ values to avoid negative values in the regression. $27 \mathrm{nmol} \mathrm{N}_{2} \mathrm{O}-\mathrm{N}$ liter ${ }^{-1}$ was the mean of the calculated saturation valucs of all water samples used in the regression. Values of $\mathrm{H}_{2} \mathrm{~S}$-containing samples were not used in the calculation, but their positions are indicated. The correlation coefficient was $r=0.978$ ( $a$ $=6.10 \times 10^{-3}, b=4.05 \times 10^{-3}$; for comparison without addition of the mean $\mathrm{N}_{2} \mathrm{O}$ saturation value: $r=0.962$; $\left.a=5.45 \times 10^{-3}, b=4.59 \times 10^{-3}\right)$. Data source as in Fig. 4.

station $\mathrm{T}$ the low oxygen water showed a pronounced supersaturation of $\mathrm{N}_{2} \mathrm{O}-$ $1,050 \%$ at $100 \mathrm{~m}$ and decreasing to $640 \%$ at $157 \mathrm{~m}$. As an overall tendency, $\mathrm{N}_{2} \mathrm{O}$ increased with increasing $\mathrm{NO}_{3}{ }^{-}+\mathrm{NO}_{2}^{-}$concentration (Fig. 5) and showed a decrease with increasing actual oxygen concentration. This relationship could be described by a reciprocal regression (Fig. 6). As with decreasing oxygen concentrations, the production of $\mathrm{N}_{2} \mathrm{O}$ as nitrification product increases (Goreau et al. 1980); the ratio of $\mathrm{N}_{2} \mathrm{O}$ vs. the sum of $\mathrm{NO}_{2}{ }^{-}+\mathrm{NO}_{3}{ }^{-}$was plotted (Fig. 7). For the low oxygen water below the halocline the ratio increased from $0.6 \%$ at $1.6 \mathrm{ml} \mathrm{O}_{2}$ liter $^{-1}$ to $\sim 2.5 \%$ at $0.1 \mathrm{ml} \mathrm{O}_{2}$ liter $^{-1}$.

Concentrations of POC in the Gotland Deep were between 43 and $318 \mu \mathrm{g} \mathrm{C}$ liter ${ }^{-1}$ in 1987 (Fig. 2D) and between 75 and 446 in 1986. Maxima were always observed in the euphotic zone and in the water near the sediment. Values were always lowest in the oxic water layer between the euphotic zone and oxic-anoxic interface. The $\mathrm{C}: \mathrm{N}$ ratio $(\mathrm{mol} \mathrm{C}: \mathrm{mol} \mathrm{N})$ had a maximum of 9.1 at

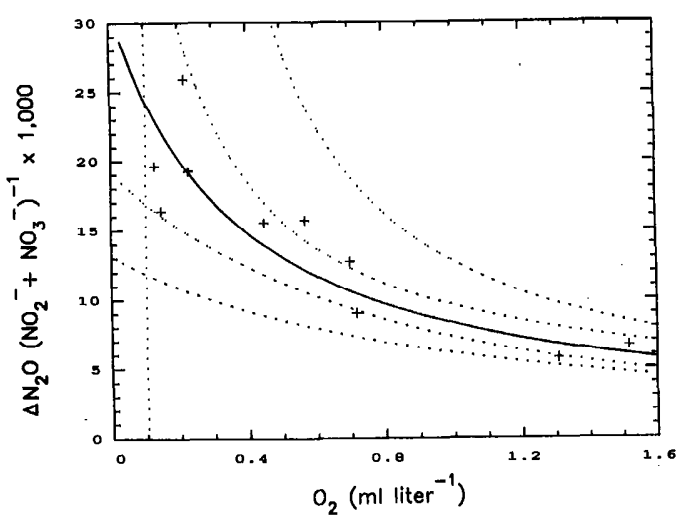

Fig. 7. Reciprocal regression of the ratio of $\Delta \mathrm{N}_{2} \mathrm{O}$ : $\left(\mathrm{NO}_{2}^{-}+\mathrm{NO}_{3}^{-}\right)$on $\mathrm{O}_{2}$ for the low oxygen water $(<2.0$ $\mathrm{ml} \mathrm{O}_{2}$ liter $\left.^{-1}\right)$ below the halocline $(r=0.937 ; a=0.032$, $b=0.089)$. Data source as in Fig. 4 .

the bottom of the halocline $(80 \mathrm{~m})$ and a minimum of 6.8 at the oxic-anoxic interface. At station T, POC concentrations (values available only for the low oxygen water between 100 and $157 \mathrm{~m}$ ) ranged between 61 $(120 \mathrm{~m})$ and $121 \mu \mathrm{g} \mathrm{C} \operatorname{liter}^{-17}(157 \mathrm{~m})$ (Fig. $3)$. The $C: N$ ratio of the $157-\mathrm{m}$ sample was 9.6.

Bacterial numbers were in the range of $0.1-4.4 \times 10^{6}$ cells $^{-1}$, with the maximum in the euphotic zone. Less pronounced peaks were in the water layer near the sediment $\left(\sim 1.8 \times 10^{6}\right)$ and, in the Gotland Deep, at the oxic-anoxic interface $\left(\sim 1.6 \times 10^{6}\right.$ cells $)$. Bacterial numbers were always lowest in the oxic water with oxygen higher than $0.2 \mathrm{ml}$ $\mathrm{O}_{2}$ liter $^{-1}$ below the euphotic zone. The mean values for the water samples from this part of the oxic layer of both stations ranged between 2.1 and $3.2 \times 10^{5}$ cells $\mathrm{ml}^{-1}$.

The numbers of aerobically growing saprophytes always reached highest values in the euphotic zone. Peaks in the halocline were less pronounced. Lowest values were usually recorded in the low oxygen water $\left(<0.2 \mathrm{ml} \mathrm{O}_{2}\right.$ liter $\left.^{-1}\right)$ of station $\mathrm{T}$ and in the anoxic water of the Gotland Deep.

In the Gotland Deep, heterotrophic $\mathrm{N}_{2} \mathrm{O}$ producing bacteria that grew in nutrientbroth-nitrate medium $\left(\mathrm{N}_{2} \mathrm{OP}\right.$ in Fig. $\left.2 \mathrm{~F}\right)$ ranged from 26 to 2,400 bacteria $\mathrm{ml}^{-1}$. In 1987 , they showed a pronounced maximum at the bottom of the halocline and another increase was noticed at the oxic-anoxic in- 

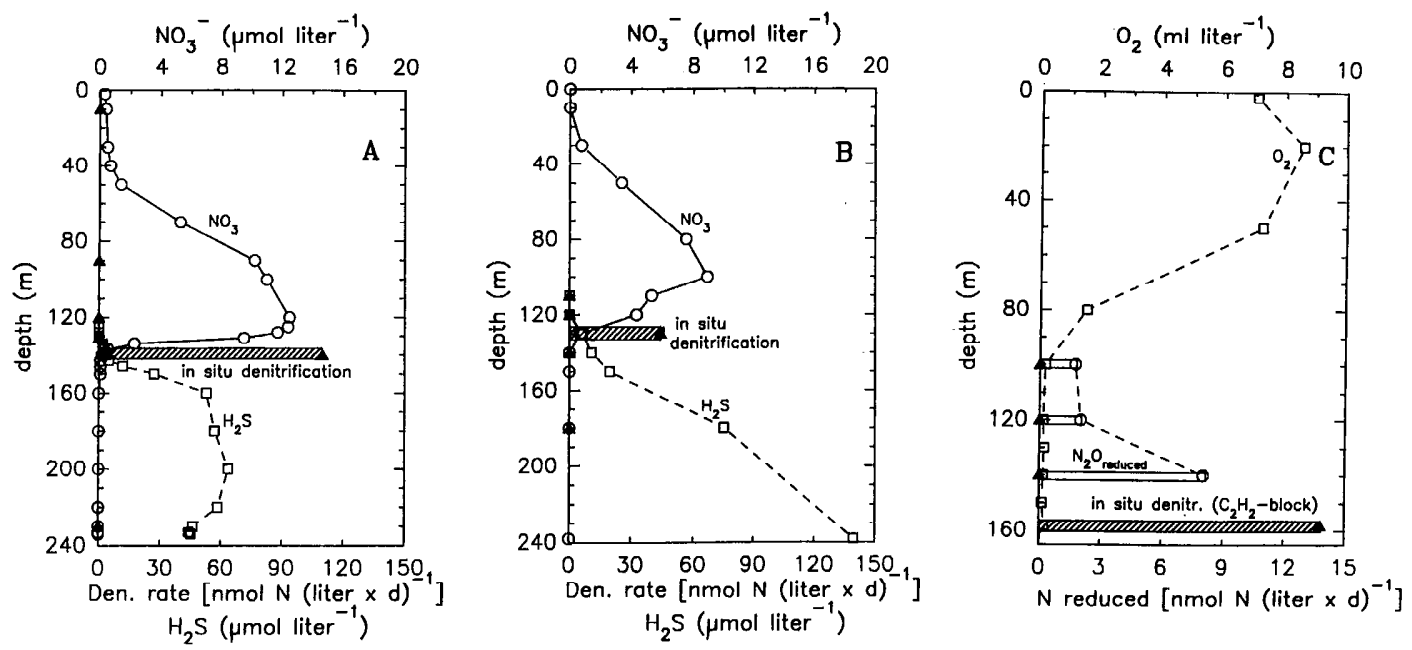

Fig. 8. In situ denitrification for the Gotland Deep in summer 1986 (A) and 1987 (B) and for station T (C) in summer 1986. For station $\mathrm{T}$, rates of $\mathrm{N}_{2} \mathrm{O}$ reduction are also shown.

terface. A strong decrease was observed in the low oxygen water between the halocline and chemocline. $\mathrm{N}_{2}$-forming bacteria $\left(\mathrm{N}_{2} \mathrm{P}\right)$ ranged from 17 to 350 bacteria $\mathrm{ml}^{-1}$. The most pronounced maximum was at the oxicanoxic interface. Counts from 1986 showed a similar trend for $\mathrm{N}_{2} \mathrm{O}$-producing and $\mathrm{N}_{2}-$ forming bacteria as that in 1987 (Brettar 1991). For station T, data are available only for samples from the low oxygen layer (see Fig. 3D): between 120 and $150 \mathrm{~m}$ numbers of $\mathrm{N}_{2} \mathrm{O}$-producing bacteria ranged from 20 to $90 \mathrm{ml}^{-1}$, and the number of $\mathrm{N}_{2}$-forming bacteria increased with depth from undetectable $\left(<0.03 \mathrm{ml} \mathrm{liter}{ }^{-1}\right)$ to $0.4 \mathrm{ml}^{-1}$.

In situ denitrification-Denitrification was measured in the water of the Gotland Deep and station $\mathrm{T}$ with emphasis on low oxygen water below the halocline. By means of the acetylene blockage method, denitrification could be detected only at the oxic-anoxic interface of the Gotland Deep (1987: 130 $\mathrm{m}, 1986: 140 \mathrm{~m})$ and in the water near the sediment $(157 \mathrm{~m})$ at station $\mathrm{T}$ (Fig. 8). The denitrifying samples from the Gotland Deep contained concomitantly low concentrations of $\mathrm{H}_{2} \mathrm{~S}$ and $\mathrm{NO}_{3}{ }^{-}$and came out of a layer with high rates of $\mathrm{CO}_{2}$ dark fixation (Gocke 1989). The rates of denitrification were higher in interface samples from the Gotland Deep (1986: 110 nmol liter ${ }^{-1} \mathrm{~d}^{-1}$; 1987: $44 \mathrm{nmol}$ liter $^{-1} \mathrm{~d}^{-1}$ ) than in samples from water near the sediment at station $\mathrm{T}$ (1986: $13.5 \mathrm{nmol}$ liter $^{-1} \mathrm{~d}^{-1}$ ). Rates were calculated from incubation periods of $4 \mathrm{~d}$. For interface samples it was shown that linearity of the denitrification rates was given for incubation periods up to $4 \mathrm{~d}$ (Brettar and Rheinheimer 1991). The endogenous $\mathrm{NO}_{3}{ }^{-}$was in no case used up in a 4-d period.

The water layer low in oxygen and far from the sediment $(100-140 \mathrm{~m})$ at station $T$ did not show any denitrification detectable by the acetylene blockage method. In this layer, reduction of $\mathrm{N}_{2} \mathrm{O}$ in samples without added acetylene was observed, whereas samples with acetylene added did not show a significant change of $\mathrm{N}_{2} \mathrm{O}$ concentration. $\mathrm{N}_{2} \mathrm{O}$ reduction was quantified after an incubation period of $12 \mathrm{~d}$. In the upper part of this low oxygen water layer, reduction of the $\mathrm{N}_{2} \mathrm{O}$ present was very low $\left(\sim 2 \mathrm{nmol} \mathrm{N}\right.$ liter $\left.^{-1} \mathrm{~d}^{-1}\right)$. Samples from 140 $\mathrm{m}$ showed a higher reduction rate of $8 \mathrm{nmol}$ $\mathrm{N}$ liter ${ }^{-1} \mathrm{~d}^{-1}$ (Fig. 8C).

Denitrification after nitrate additionDenitrification after $\mathrm{NO}_{3}^{-}$addition was measured in all samples where in situ denitrification was measured (Fig. 9). This comparison should indicate if the availability of $\mathrm{NO}_{3}{ }^{-}$had an influence on the rate of denitrification in samples where in situ denitrification occurred or on extension of the denitrification layer. 

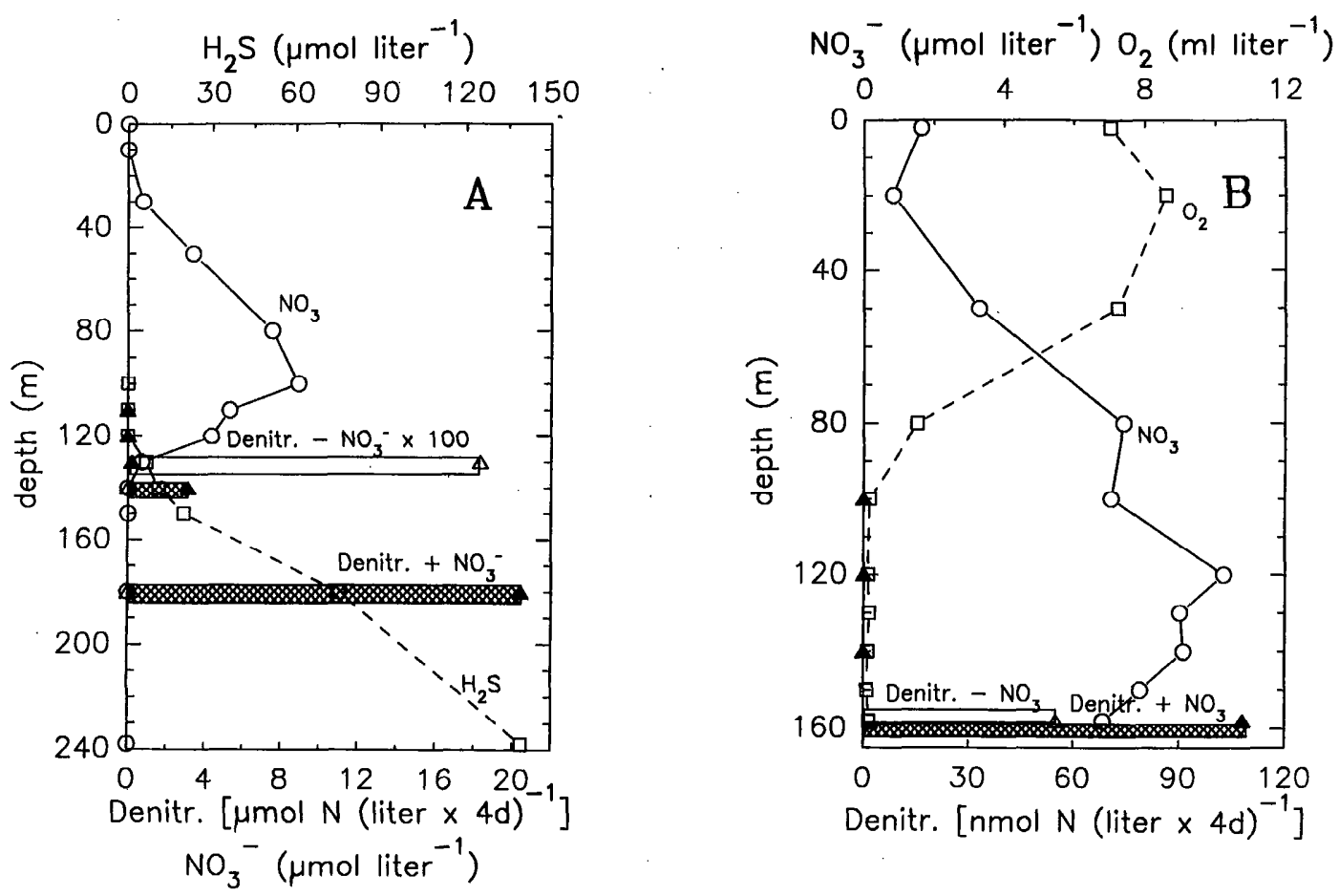

Fig. 9. Denitrification with and without added $\mathrm{NO}_{3}{ }^{-}$after a 4-d incubation. Data shown are from the Gotland Deep in 1987 (A) and station T in 1986 (B).

Denitrification was enhanced only in samples from water near the sediment from station $\mathrm{T}$ (Fig. 9B). The in situ rate was doubled by adding $50 \mu \mathrm{mol} \mathrm{NO}_{3}{ }^{-}$liter $^{-1}$, although in situ denitrification consumed $<1 \%$ of the endogenous $\mathrm{NO}_{3}{ }^{-}$within $12 \mathrm{~d}$. In the Gotland Deep, no enhancement of denitrification was observed.

Samples from the sulfide-free water of the Gotland Deep or station $T$ that did not show in situ denitrification (=without any addition except acetylene) never showed denitrification after $\mathrm{NO}_{3}{ }^{-}$was added, which was also the case for incubation periods up to $12 \mathrm{~d}$ for samples with acetylene added or incubations up to $100 \mathrm{~d}$ without added acetylene.

In contrast, sulfide-containing and $\mathrm{NO}_{3}{ }^{-}$ free samples from the anoxic water of the Gotland Deep showed denitrification after $\mathrm{NO}_{3}{ }^{-}$was added. The amount of $\mathrm{NO}_{3}{ }^{-} \mathrm{fi}-$ nally reduced increased with increasing $\mathrm{H}_{2} \mathrm{~S}$ concentration (see Fig. 9A).

Denitrification after addition of electron
donors-Denitrification in water samples from the oxic-anoxic interface of the Gotland Deep (1987) was strongly enhanced by adding $\mathrm{H}_{2} \mathrm{~S}, \mathrm{~S}_{2} \mathrm{O}_{3}{ }^{-}$, and acctatc as electron donors plus $\mathrm{NO}_{3}{ }^{-}$. The interface samples displayed a very strong increase in denitrification rate within $2 \mathrm{~d}$ at $4.5^{\circ} \mathrm{C}$ after adding the above substrates. This increase was not observed when $\mathrm{NO}_{3}{ }^{-}$was added without electron donors. The utility of reduced sulfur compounds as electron donors for denitrification was shown in more detail by Brettar and Rheinheimer (1991).

Water samples from the nondenitrifying water far from the sediment $(120 \mathrm{~m})$ at station $\mathrm{T}$ were tested for denitrification after adding glucose $+\mathrm{NO}_{3}^{-}$, acetate $+\mathrm{NO}_{3}^{-}$, and $\mathrm{NO}_{3}{ }^{-}$only. Figure 10 shows the reaction of the samples during an 8-d incubation period with and without added acetylene. No change of the nitrogenous compounds $\mathrm{NO}_{2}^{-}, \mathrm{NO}_{3}^{-}, \mathrm{NH}_{4}{ }^{+}$, and $\mathrm{N}_{2} \mathrm{O}$ was observed during the first $4 \mathrm{~d}$ of incubation for all assays. After $8 \mathrm{~d}$, samples with acetate and 

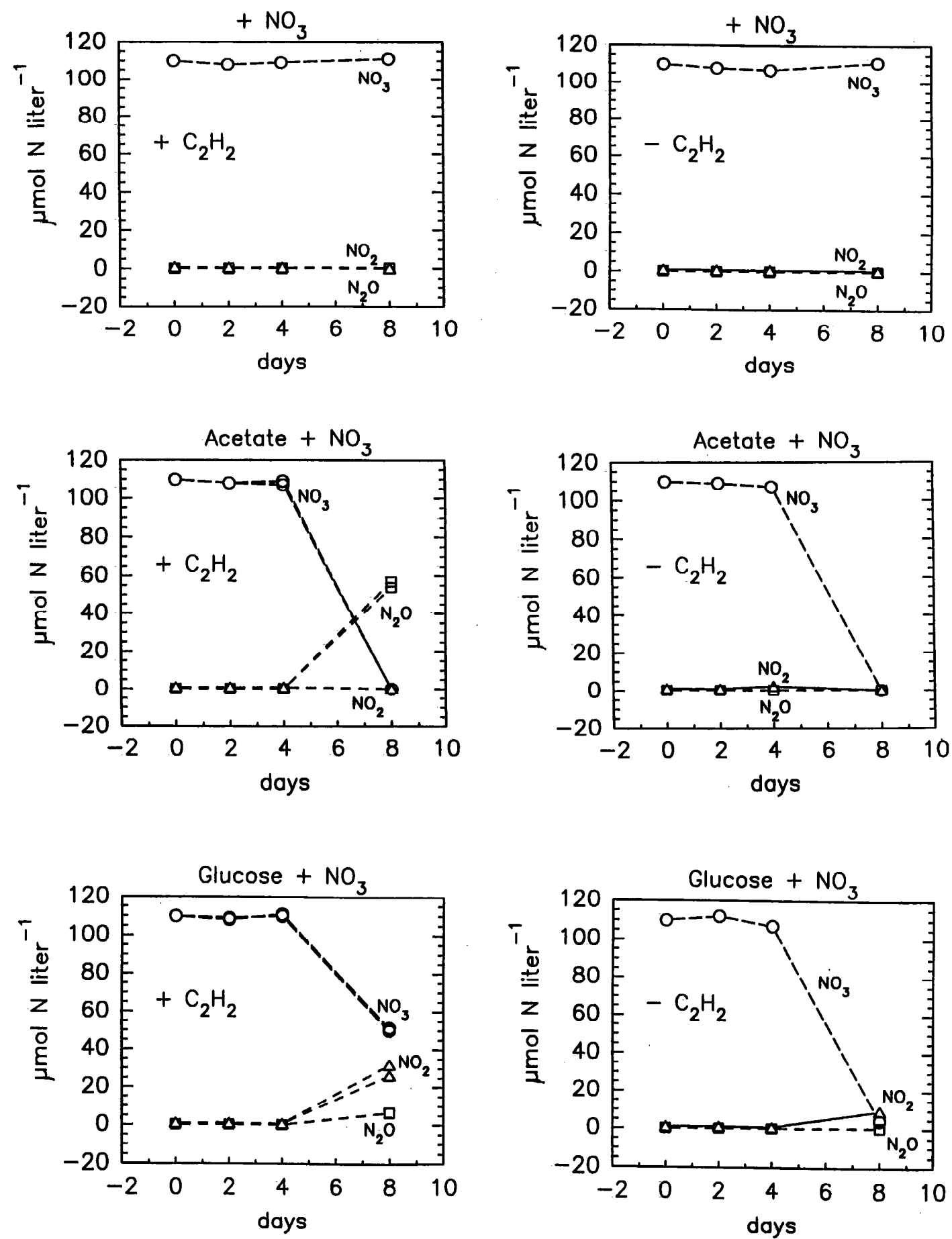

Fig. 10. Denitrification in water samples from the low oxygen water of station $T(120 \mathrm{~m})$. At sampling time, concentrations were $0.14 \mathrm{ml} \mathrm{O}$ liter $^{-1}, 1.4 \mu \mathrm{mol} \mathrm{NO}_{2}^{-}$liter $^{-1}, 8.7 \mu \mathrm{mol} \mathrm{NO}_{3}{ }^{-1}$ liter $^{-1}$, and $0.6 \mu \mathrm{mol} \mathrm{NH}_{4}^{+}$liter $^{-1}$.

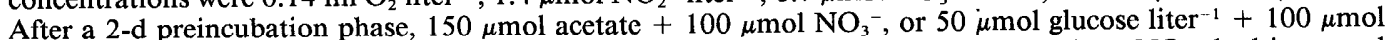
$\mathrm{NO}_{3}^{-}$liter ${ }^{-1}$, or $100 \mu \mathrm{mol} \mathrm{NO}{ }^{-}$liter ${ }^{-1}$ only were added. During the preincubation phase $\mathrm{NO}_{3}^{-}$had increased to $9.8 \mu \mathrm{mol}$ liter ${ }^{1}, \mathrm{NO}_{2}{ }^{-}$decreased to $1.0 \mu \mathrm{mol}$ liter $^{-1}$, and denitrification was not detectable. Assays with $\mathrm{C}+$ acetylene added were done as duplicates; results of both parallels are shown (same line and point symbols used for duplicates). 
Table 1. Initial POC concentration $\left(\mathrm{POC}^{0}\right)$, $\mathrm{POC}$ change $(\Delta \mathrm{POC}), \mathrm{NO}_{2}^{-}$increase $\left(\Delta \mathrm{NO}_{2}{ }^{-}\right)$, initial $\mathrm{O}_{2}$ concentration $\left(\mathrm{O}_{2}{ }^{\circ}\right)$, and $\mathrm{O}_{2}$ consumption $\left(\Delta \mathrm{O}_{2}{ }^{\mathrm{POC}}\right.$, calculated for $\mathrm{POC}$ degradation) for samples from the low oxygen water incubated for $100 \mathrm{~d}$. Values given are means of duplicates.

\begin{tabular}{|c|c|c|c|c|c|c|}
\hline \multirow[b]{2}{*}{ Sta. } & \multirow{2}{*}{$\begin{array}{c}\text { Depth } \\
\text { (m) }\end{array}$} & $\mathrm{POC}^{\circ}$ & $\triangle \mathrm{POC}$ & \multirow{2}{*}{$\begin{array}{c}\Delta \mathrm{NO}_{2} \\
\left(\mu \mathrm{mol}^{-1 i t e r}{ }^{-1}\right)\end{array}$} & $\mathrm{O}_{2}{ }^{\circ}$ & $\Delta \mathrm{O}_{2}{ }^{\mathrm{POC}}$ \\
\hline & & \multicolumn{2}{|c|}{$\left(\mu \mathrm{g} C\right.$ liter $\left.{ }^{\prime}\right)$} & & \multicolumn{2}{|c|}{$\left(\mathrm{ml}\right.$ liter $\left.{ }^{\prime}\right)$} \\
\hline Gotland & 120 & 74.7 & -39.0 & 0 & 1.30 & -0.15 \\
\hline Gotland & 130 & 82.7 & -33.4 & 0 & 0.71 & -0.12 \\
\hline Gotland & 140 & 84.9 & $+42: 6$ & +3.2 & 0.13 & - \\
\hline $\mathrm{T}$ & 120 & 60.6 & -4.1 & 0 & 0.14 & -0.02 \\
\hline
\end{tabular}

glucose added showed denitrification. No denitrification could be detected in samples where only $\mathrm{NO}_{3}{ }^{-}$was added. The fact that denitrification was much faster after adding acetate than with glucose was obviously due to the added acetylene, as the comparison of the samples with and without acetylene reveals. Acetylene obviously had a retarding effect on samples with glucose added.

$P O C$ degradation in low oxygen water samples-The observation that there was no denitrification without added electron donors in samples away from interfaces was also confirmed by the results from incubation of 1 liter of water from the low oxygen water of the Gotland Deep (1986: $120 \mathrm{~m}$, $130 \mathrm{~m}, 140 \mathrm{~m})$ and of station $\mathrm{T}(120 \mathrm{~m})$ for $100 \mathrm{~d}$. These samples were identical to those where in situ denitrification (with acetylenc added) was measured. No acetylene, but 500 $\mu \mathrm{mol} \mathrm{NO}_{3}{ }^{-}$liter ${ }^{-1}$, was added. Except for the interface sample (Gotland, $140 \mathrm{~m}$ ) where formation of $3.2 \mu \mathrm{mol} \mathrm{NO}_{2}{ }^{-}$liter $^{-1}$ was observed, monitoring of the nitrogen oxides did not give any hint on reduction of the added $\mathrm{NO}_{3}{ }^{-}$.

Changes of POC during the 100-d incubation period are listed in Table 1 . As the bacterial biomass in the filtrate of the GF/F filters never exceeded $1 \mu \mathrm{g} \mathrm{Cliter}{ }^{-1}$, different retainments of the bacterial cells on the filter due to changes of the mean cell volume during incubation should not have introduced a major error to the POC measurements. The low oxygen samples from the Gotland Deep showed changes in POC content of between 33 and $39 \mu \mathrm{g} \mathrm{C}$ liter $^{-1}$. The interface sample showed an increase, rather than a decrease, of the initial POC content of 85 $\mu \mathrm{g} \mathrm{C}$ liter $^{-1}$. The sample from station T $(120$ $\mathrm{m})$ showed only a minor decrease from 60.6 to $56.5 \mu \mathrm{g} \mathrm{liter}^{-1}$ within $100 \mathrm{~d}$. With the simplifying assumption that the decrease of POC means degradation to $\mathrm{CO}_{2}$, the amount of oxygen consumed or $\mathrm{NO}_{3}{ }^{-}$reduced was calculated from the difference in POC content according to Liu and Kaplan (1984) (1 $\mu \mathrm{mol}$ POC consumed $=1 \mu \mathrm{mol} \mathrm{O}_{2}$ consumed or $0.8 \mathrm{~mol} \mathrm{NO}_{3}{ }^{-}$reduced to $\mathrm{N}_{2}$ or 2 mol $\mathrm{NO}_{3}{ }^{-}$reduced to $\mathrm{NO}_{2}{ }^{-}$).

According to these assumptions and conversion factors, the decrease of POC observed (degradation assumed) in the low oxygen water, samples from above the interface (Gotland Deep) may have consumed 2.75 and $3.25 \mu \mathrm{mol} \mathrm{O}_{2}$ liter $^{-1}$, respectively, within $100 \mathrm{~d}$. The oxygen concentration would have been lowered to $1.15 \mathrm{ml} \mathrm{O}_{2}$ liter $^{-1}$ in the $120-\mathrm{m}$ sample and to 0.59 in the $130-\mathrm{m}$ sample. If the POC degradation was used for denitrification, $2.6(120 \mathrm{~m})$ and $2.2(130$ m) $\mu \mathrm{mol} \mathrm{NO}{ }_{3}^{-}$liter $^{-1}$ could have been reduced to $\mathrm{N}_{2}$. For samples from the low oxygen water of station $T(120 \mathrm{~m})$, the amount of POC that disappeared could have been used for a maximum oxygen consumption of $0.34 \mu \mathrm{mol}$ liter ${ }^{1}$, thereby reducing the oxygen concentration to $0.12 \mathrm{ml}$ liter $^{-1}$ or for a maximum reduction of $0.27 \mu \mathrm{mol} \mathrm{NO}{ }_{3}{ }^{-}$ liter $^{-1}$ to $\mathrm{N}_{2}$.

\section{Discussion}

Restriction of denitrification to electron donor-rich interfaces-Measurements in the Gotland Deep and station $\mathrm{T}$ showed that denitrification was restricted to interfaces like the oxic-anoxic and the sediment-water. These interfaces seemed to bc the only places where conditions were appropriate for denitrification.

As shown by $\mathrm{NO}_{3}{ }^{-}$addition experiments at both stations, $\mathrm{NO}_{3}{ }^{-}$was not the factor that restricted extension of the denitrification zone. An increase of the denitrification 
rate was observed only with $\mathrm{NO}_{3}{ }^{-}$addition to water near the sediment at station $\mathrm{T}$. Consumption of $<1 \%$ of the endogenous $\mathrm{NO}_{3}{ }^{-}$in the samples without $\mathrm{NO}_{3}{ }^{-}$added indicates that the $\mathrm{NO}_{3}{ }^{-}$concentration obviously had a kinetic control (higher $\mathrm{NO}_{3}{ }^{-}$ concentration needed for saturation of the enzymes involved than the actual $\mathrm{NO}_{3}{ }^{-}$ concentration), but was not the limiting factor in denitrification.

Limitation of denitrification by available organic $C$ in water far from the sedimentThe availability of organic $C$ seemed to be the factor that restricted denitrification to electron donor-rich interfaces. This influence was most obvious for the low oxygen water at station $\mathrm{T}$. Although $\mathrm{NO}_{3}{ }^{-}$and oxygen concentrations were adequate for denitrification from $100 \mathrm{~m}$ down to the sediment $(163 \mathrm{~m})$, denitrification was detectable by the acetylene blockage method only in water near the sediment $(157 \mathrm{~m})$. Water far from the sediment did not seem to provide enough organic $\mathrm{C}$ for denitrification.

C limitation is also indicated by the experiments with water samples far from the sediment $(120 \mathrm{~m})$ of station $\mathrm{T}$ where adding acetate or glucose, but not $\mathrm{NO}_{3}{ }^{-}$alone resulted in denitrification. The long lag phase of $>4 \mathrm{~d}$ until denitrification started can be interpreted as the absence of an actively denitrifying microflora. Probably only a few of the denitrifiers responsible for the final denitrification were present at the beginning of the incubation, and the long lag phase was due to the time needed for growth of the denitrifiers. This assumption is supported by the low number of $\mathrm{N}_{2} \mathrm{O}$ - and extremely low number of $\mathrm{N}_{2}$-producing bacteria detected in the relevant sample as well as in the whole of the low oxygen water of this station. A reason for the low numbers of denitrifiers in the water far from the sediment at station $T$ could be a longer lasting supply low in organic material. Low uptake rates for glucose, acetate, and lactate wcre reported by Rheinheimer et al. (1989) and Gocke (1989) for the whole oxic water column between the euphotic layer and chemocline of the central Baltic. These findings may hint at low availability of organic C. A low $\mathrm{C}$ supply is also indicated by the low
POC degradation during a 100-d incubation period.

The dependence of the number of denitrifiers on the availability of organic $C$ was already shown by Tiedje (1988). It could be assumed that a longer lasting low $\mathrm{C}$ supply in the low oxygen water of station $\mathrm{T}$ resulted in the synergistic effect of reducing the denitrifying microflora and limiting the denitrification rate by supply of $\mathrm{C}$ that was too low.

A similar situation in terms of low C supply could also occur in the low oxygen water between the halocline and the chemocline of the Gotland Deep: similar low POC content, a pronounced decrease of the numbers of denitrifying bacteria, and the finding that denitrification did not occur within $100 \mathrm{~d}$ of incubation may demonstrate the comparability of the situation. Occasional input of organic $\mathrm{C}$ provided by the high chemosynthetic activity of the interface layer (Gocke 1989) may be responsible for the higher availability of POC in this layer compared to the low oxygen water of station $T$.

Nitrification-denitrification coupling as an energetically more favorable alternative in $C$-poor environments - There was no reduction of $\mathrm{NO}_{3}{ }^{-}, \mathrm{NO}_{2}{ }^{-}$, or $\mathrm{NO}$ that resulted in production of $\mathrm{N}_{2} \mathrm{O}$ in the presence of acetylene in samples of water far from the sediment at station $T$. We conclude therefore that no denitrification in the classical sense starting from $\mathrm{NO}_{3}{ }^{-}$or $\mathrm{NO}_{2}^{-}$occurred. In contrast, reduction of $\mathrm{N}_{2} \mathrm{O}$ with rates increasing toward the sediment could be seen (see Fig. 8C). In the following we will differentiate between $\mathrm{N}_{2} \mathrm{O}$ reduction and denitrification. The term denitrification is used to define the reduction of $\mathrm{NO}_{3}{ }^{-}, \mathrm{NO}_{2}{ }^{-}$, and $\mathrm{NO}$, resulting in detection of $\mathrm{N}_{2} \mathrm{O}$ with the acetylene inhibition method. $\mathrm{N}_{2} \mathrm{O}$ reduction describes the process of $\mathrm{N}_{2} \mathrm{O}$ reduction in the absence of acetylene.

Coincidence of the inability to denitrify $\mathrm{NO}_{3}{ }^{-}$and $\mathrm{NO}_{2}{ }^{-}$and the ability of $\mathrm{N}_{2} \mathrm{O}$ reduction under conditions of low $\mathrm{C}$ supply substantiated the hypothesis that reduction of $\mathrm{N}_{2} \mathrm{O}$ could be energetically more favorable per mole of electrons consumed than the reduction of the less-reduced nitrogen oxides. According to our hypothesis that no 
Table 2. Changes of free energy $\left(\Delta G^{0 \prime}\right)$ for the reduction of different nitrogen oxides. All calculations refer to $\mathrm{pH} 7.0$.

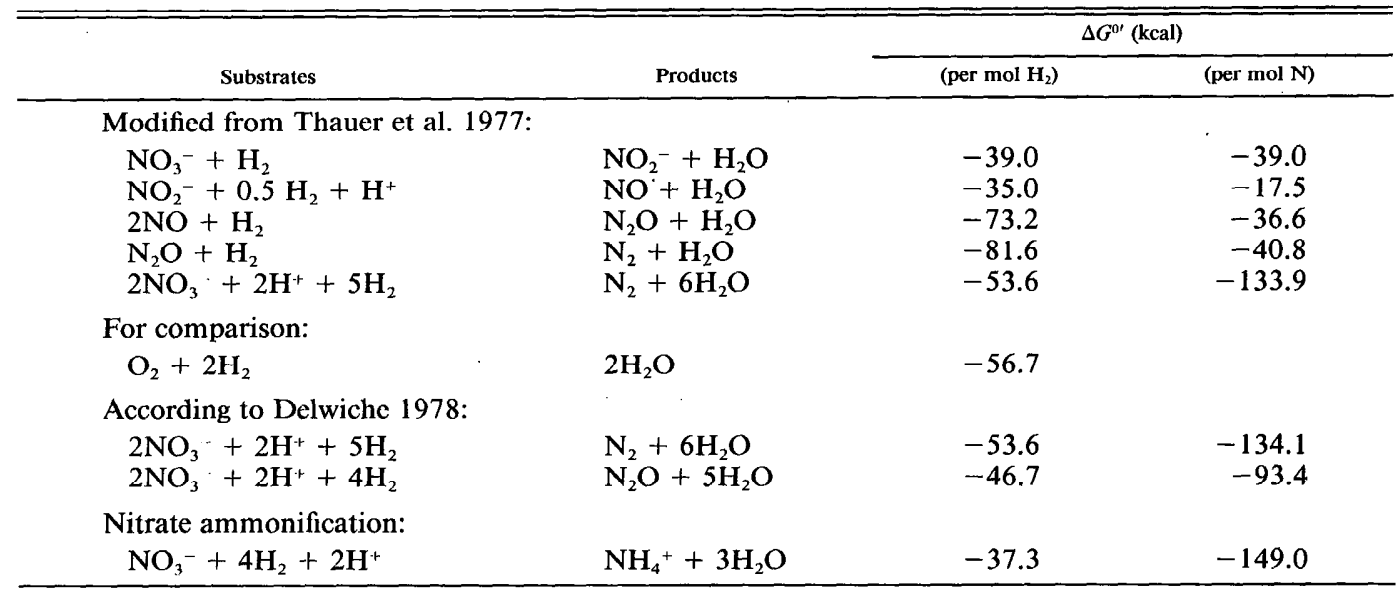

microflora was present in water far from the sediment that was able to denitrify under the given conditions, we further assume that the bacteria that reduced $\mathrm{N}_{2} \mathrm{O}$ were not denitrifying bacteria. The ability to reduce $\mathrm{N}_{2} \mathrm{O}$ must not necessarily have been coupled to the capability to reduce $\mathrm{NO}_{3}{ }^{-}$or $\mathrm{NO}_{2}{ }^{-}$.

Under conditions of $\mathrm{C}$ limitation, reduction of $\mathrm{N}_{2} \mathrm{O}$ should be thermodynamically more favorable than reduction of the lessreduced nitrogen oxides, as can be seen from the free energy changes (according to Thauer et al. 1977) (Table 2). Reduction of $\mathrm{N}_{2} \mathrm{O}$ provides double the amount of energy per electron consumed than reduction of $\mathrm{NO}_{3}{ }^{-}$ or $\mathrm{NO}_{2}{ }^{-}$. In this case energy is calculated for $\mathrm{pH} 7.0$ with $\mathrm{H}_{2}$ as electron donor. To our knowledge, there are no known bacteria that can convert this higher free energy change to a higher ATP yield than that obtained from reduction of the less-reduced nitrogen oxides (i.e. $\mathrm{NO}_{3}{ }^{-}, \mathrm{NO}_{2}{ }^{-}$, and $\mathrm{NO}$ ). The preferred reduction of $\mathrm{N}_{2} \mathrm{O}$ observed in the water column suggests that there were bacteria present able to utilize it. Perhaps they are "normal" aerobic bacteria, with an additional ability to use high concentrations of $\mathrm{N}_{2} \mathrm{O}$, especially when oxygen is low. Such an organism could use the higher energy yield usually obtained by aerobic degradation of organic compounds compared to denitrification (Boogerd et al. 1984; Koike and Hattori 1975) and additionally being more versatile in the case of low oxygen concentrations. $\mathrm{N}_{2} \mathrm{O}$ reduction is probably relevant only in environments with low oxygen and high $\mathrm{N}_{2} \mathrm{O}$ concentrations. It may provide an energetically favorable path to use high $\mathrm{N}_{2} \mathrm{O}$ concentrations at a given low $\mathrm{C}$ supply.

The high $\mathrm{N}_{2} \mathrm{O}$ concentrations are likely to be the product of nitrification. A hint on that could be the linear increase of the $\mathrm{N}_{2} \mathrm{O}$ concentration with increasing $\mathrm{NO}_{3}{ }^{-}+\mathrm{NO}_{2}-$ concentrations (see Fig. 5). Also, the increasing ratio of $\mathrm{N}_{2} \mathrm{O}$ vs. the sum of the nitrification products $\mathrm{NO}_{3}^{-}$and $\mathrm{NO}_{2}^{-}$with decreasing oxygen concentrations is in the same range as that reported for Nitrosomonas sp. by Goreau et al. (1980). For Nitrosomonas $\mathrm{sp}$. the ratio increased from $\sim 0.6 \%$ at $1.6 \mathrm{ml} \mathrm{liter}{ }^{-1}$ to $10 \%$ at $0.13 \mathrm{ml} \mathrm{litcr}{ }^{-1}$. For the same range of oxygen concentrations the ratio increased from 0.6 to $2.5 \%$ in the low oxygen water below the halocline (see Fig. 7). The lower ratio for the lower oxygen concentrations may have several causes, starting with the physiology of the present nitrifiers. However, as consumption processes by $\mathrm{N}_{2} \mathrm{O}$-reducing organisms have been shown to occur, it is most likely that these reduction processes will counteract $\mathrm{N}_{2} \mathrm{O}$ accumulation.

Nitrification as the most important source for nitrous oxides has been pointed out by Hahn (1981) for the oceans, and a dominant role for the Baltic was shown by Rönner 


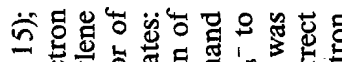

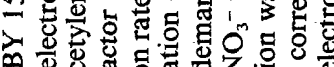

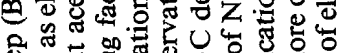

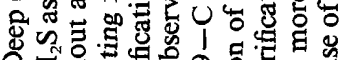

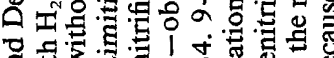
t马s

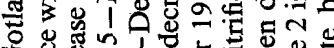

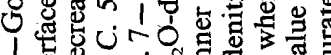
寸

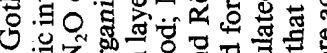
1 중 $\because$ 击

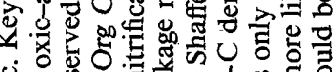
c. ๓

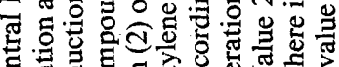

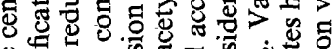

它O色 I

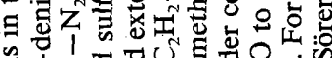

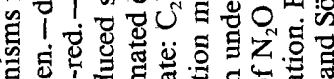

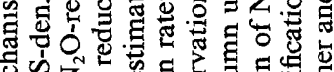

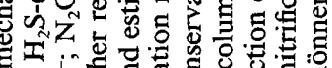
c.

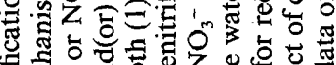

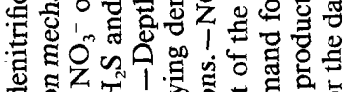

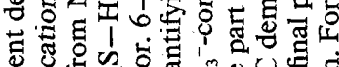
密它

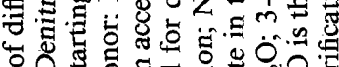
은

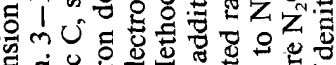

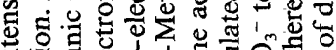

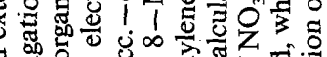

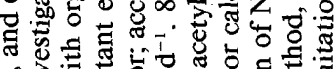

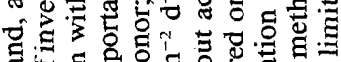

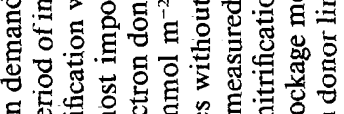
5.

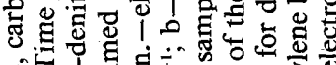

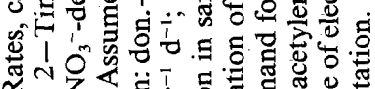
«

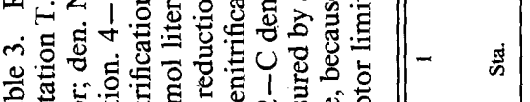

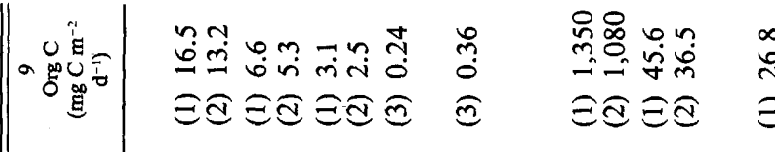

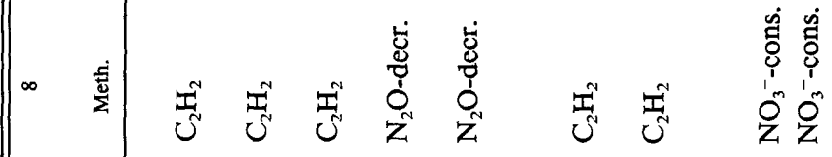
, |

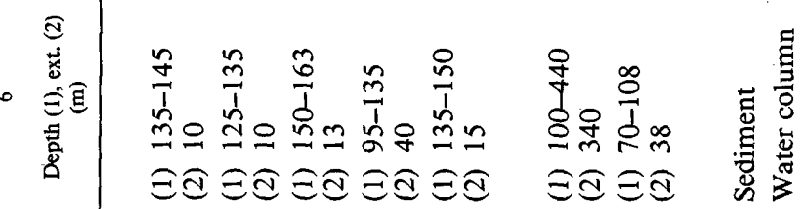

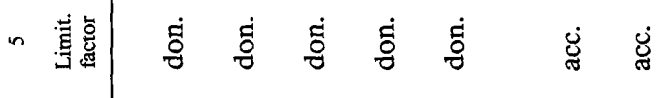
9

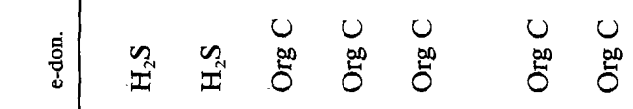

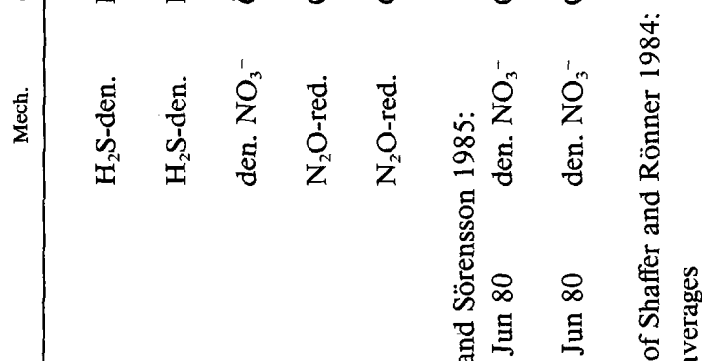

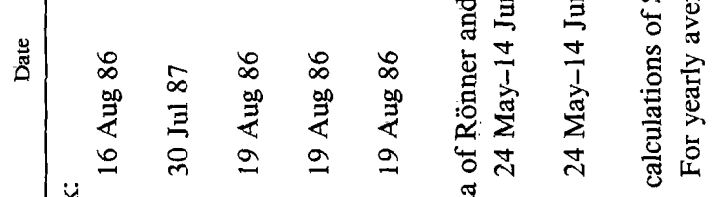


(1983a). That even strong nitrification by marine bacteria is possible under low oxygen $\left(0.1 \mathrm{ml} \mathrm{liter}^{-1}\right)$ concentrations has been reported by Carlucci and McNally (1969). For the low oxygen water of the Baltic proper, high rates of nitrification have been reported by Enoksson (1986) and have also been observed as $\mathrm{NO}_{3}{ }^{-}$increase during incubation of the water samples during this investigation.

The relevance of the reduction of $\mathrm{N}_{2} \mathrm{O}$ produced by nitrification was first demonstrated by Codispoti and Christensen (1985). They showed that this mechanism can play a major role for nitrogen transformations at the boundary of oxygen-deficient waters $(0.1$ ml liter ${ }^{-1}$ ) in the eastern tropical South $\mathrm{Pa}$ cific Ocean.

Changing $C$ supply in the course of the year as followed by corresponding denitrification rates - In this paper we drew a picture of C-limited denitrification in the central Baltic. Our findings are in contrast with those of Rönner and Sörensson (1985). Their investigations, made in late spring 1980, indicated $\mathrm{NO}_{3}{ }^{-}$-limited denitrification that concerned much more extended parts of the water column, usually from below the halocline down to the sediment. Their rates were 2-10 times as high as those reported here.

Calculations of the organic $\mathrm{C}$ needed as electron donor for the denitrification rates measured in the Baltic proper are given in Table 3. Calculations are based on the assumption that denitrification of $1 \mathrm{~mol} \mathrm{NO}_{3}^{-}$ consumes $1.25 \mathrm{~mol} \mathrm{C}_{\text {org }}$ for reduction to $\mathrm{N}_{2}$ or $1 \mathrm{~mol} \mathrm{C}_{\text {org }}$ for reduction to $\mathrm{N}_{2} \mathrm{O}$, as suggested by Liu and Kaplan (1984). Table 3 demonstrates that a high $\mathrm{C}$ supply in the water is necessary to sustain the high rates and the large denitrification layers reported by Rönner and Sörensson (1985). In contrast, rates and extension of the denitrification layers reported here demand a $\mathrm{C}$ supply that is less by 1-3 orders of magnitude. Rahm (1987) calculated the C consumption in a depth profile of the Baltic. His calculations suggest that the maximum amount of $\mathrm{C}$ available in the relevant depths for denitrification is about an order of magnitude lower than that needed for the rates measured by Rönner and Sörensson. 
As demonstrated by these calculations, the most likely explanation for the different findings by Rönner and Sörensson (1985) and this study should be the different $C$ supply in the central Baltic during the course of the year. Late spring-the investigation period of Rönner and Sörensson - is the time period that displays the highest $C$ supply in the water column due to sedimentation of the spring bloom (Elmgren 1989). Our investigation period in the end of July to midAugust usually shows a much lower C supply in the water. This situation is more representative for most times of year (Stigebrandt and Wulff 1987). A high C supply in late spring may explain the higher rates, the more extended denitrification layer, and the observed $\mathrm{NO}_{3}$ limitation of denitrification. Because the low $\mathrm{C}$ supply is the typical situation for most of the year, a C-limited denitrification, restricted to the interfaces, is likely to be more representative for the year's average. Splitting the year into short periods of high denitrification and long-lasting periods of low denitrification can result in a $\mathrm{C}$ demand for denitrification that is in the range of Rahm's (1987) calculations. Additionally, it explains the high $\mathrm{N}$ loss observed in the deep water of the Baltic proper (Rönner 1983b; Shaffer and Rönner 1984).

The phenomenon of C-limited denitrification during a large portion of the year should be taken into account in calculating future denitrification capacities in the Baltic. On the basis of the observed $\mathrm{C}$ limitation, it cannot be assumed that a continual increased anthropogenic $\mathrm{N}$ load will be compensated by denitrification.

\section{References}

Andersen, T. K., M. H. Jensen, ANd J. Sørensen. 1984. Diurnal variation of nitrogen cycling in coastal, marine sediments. 1. Denitrification. Mar. Biol. 83: 171-176.

Balderston, W. L., B. Sherr, AND W. J. Payne. 1976. Blockage by acetylene of nitrous oxide reduction in Pseudomonas perfectomarinus. Appl. Environ. Microbiol. 31: 504-508.

Boogerd, F. C., H. W. van Versefeld, D. TorenvliET, M. Braster, ANd A. H. Stouthammer. 1984. Reconsideration of the efficiency of energy transduction in Paracoccus denitrificans during growth under a variety of culture conditions. Arch. Microbiol. 139: 344-350.
BRetTAR, I. 1991. Denitrifikation in der zentralen Ostsee: Regulationsfaktoren und mikrobiologische Aspekte. Ph.D. thesis, Univ. Kiel, Ber. Inst. Mecreskd. Kiel 208. 145 p.

-, AND G. RHEINHEIMER. 1991. Denitrification in the central Baltic: Evidence for $\mathbf{H}_{2} \mathrm{~S}$-oxidation as motor of denitrification at the oxic-anoxic interface. Mar. Ecol. Prog. Ser. 77: 157-169.

Carlucci, A. F., and P. M. McNally. 1969. Nitrification by marine bacteria in low concentrations of substrate and oxygen. Limnol. Oceanogr. 14: 736-739.

Codispoti, L. A., AND J. P. Cirristensen. 1985. Nitrification, denitrification and nitrous oxide cycling in the eastern tropical South Pacific Ocean. Mar. Chem. 16: 277-300.

Delwiche, C. C. 1978. Biological production and utilization of $\mathrm{N}_{2} \mathrm{O}$. Pure Appl. Geophys. 116: 414422.

DE MAN, J. C. 1975. The probability of most probable numbers. Eur. J. Appl. Microbiol. 1: 67-78.

Elmgren, R. 1989. Man's impact on the ecosystem of the Baltic Sea: Energy flows today and at the turn of the century. Ambio 18: 326-332.

ENOKSSON, V. 1986. Nitrification rates in the Baltic Sea. Comparison of three isotope techniques. Appl. Environ. Microbiol. 51: 244-250.

Fonselius, S. H. 1983. Determination of hydrogen sulphide, p. 73-80. In $\mathrm{K}$. Grasshoff et al. [eds.], Methods of seawater analysis. Verlag Chemie.

Gocke, K. 1989. Bakterielle Stoffaufnahme im aeroben und anaeroben Milieu der Ostsee. Ber. Inst. Meereskd. Kiel 188: 40-47.

GoERING, J. J. 1985. Marine denitrification, p. 192224. In H. L. Goltermann [ed.], Denitrification in the nitrogen cycle. Plenum.

GOREAU, T. J., AND OTHERS. 1980. Production of $\mathrm{NO}_{2}{ }^{-}$and $\mathrm{N}_{2} \mathrm{O}$ by nitrifying bacteria at reduced concentrations of oxygen. Appl. Environ. Microbiol. 40: 526-532.

Graneli, E., K. Wallström, W. Graneli, and R. ELMGREN. 1990. Nutrient limitation of primary production in the Baltic Sea area. Ambio 19: 142151.

GrASSHOFF, K. 1983. Determination of oxygen, thiosulphate, nitrite and nitrate, p. 61-72, 81-84, 139142, 143-150. In K. Grasshoff et al. [cds.], Methods of seawater analysis. Verlag Chemie.

HaHN, J. 1981. Nitrous oxide in the oceans, p. 191240. In C. C. Delwiche [ed.], Denitrification, nitrification and atmospheric nitrous oxide. Wiley.

HATTORI, A. 1983. Denitrification and dissimilatory nitrate reduction, p. 191-232. In E. J. Carpenter and D. G. Capone [eds.], Nitrogen in the marine environment. Academic.

KOIKE, I., AND A. HATTORI. 1975. Growth yield of a denitrifying bacterium: Pseudomonas denitrificans under aerobic and denitrifying conditions. J. Gen. Microbiol. 88: 1-10.

KOROLEFF, F. 1983. Determination of ammonia, p. 150-157. In K. Grasshoff et al. [eds.], Methods of seawater analysis. Verlag Chemie.

LiU, K. K., AND I. R. Kaplan. 1984. Denitrification rates and availability of organic matter in marine environments. Earth Planet. Sci. Lett. 68: 88-100. 
Oppenheimer, C. H., And C. E. ZoBell. 1952. The growth and viability of sixty-three species of marine bacteria as influenced by hydrostatic pressure. J. Mar. Res. 11: 10-18.

RaHM, L. 1987. Oxygen consumption in the Baltic proper. Limnol. Occanogr. 32: 973-978.

RheinHeimer, G., K. Gocke, AND H. G. Hoppe. 1989. Vertical distribution of microbiological and hydrographic-chemical parameters in different areas of the Baltic Sea. Mar. Ecol. Prog. Ser. 52: 55-70.

RöNNER, U. 1983a. Distribution, production and consumption of nitrous oxide in the Baltic Sea. Geochim. Cosmochim. Acta 47: 2179-2188.

- $1983 b$. Biological nitrogen transformations in marine ecosystems with emphasis on denitrification. Ph.D. thesis, Univ. Göteborg. 123 p.

1985. Nitrogen transformations within the Baltic proper: Denitrification counteracts eutrophication. Ambio 14: 1241-1243.

$\longrightarrow$, AND F. SöRENSSON. 1985. Denitrification rates in the low-oxygen waters of the stratified Baltic proper. Appl. Environ. Microbiol. 50: 801-806.

SHAFFER, G., AND U. RöNNER. 1984. Denitrification in the Baltic proper deep water. Deep-Sea Res. 31: 197-220.

SReEnivasan, A., AND R. VenkAtarman. 1956. Marine denitrifying bacteria from South India. J. Gen. Microbiol. 15: 241-247.

Stigebrandt, A., AND F. WULFF. 1987. A model for the dynamics of nutrients and oxygen in the Baltic proper. J. Mar. Res. 45: 729-759.
Thauer, R. K., K. JungermanN, AND K. Decker. 1977. Energy conscrvation in chemotrophic anaerobic bacteria. Bacteriol. Rev. 41: 100-180.

TiedJE, J. M. 1988. Ecology of denitrification and dissimilatory nitrate reduction to ammonium, $\mathrm{p}$. 179-244. In A. Zehnder [ed.], Biology of anaerobic microorganisms. Wiley.

Weiss, R. F., AND B. A. Price. 1980. Nitrous oxide solubility in water and seawater. Mar. Chem. 8: 347-359.

WULFF, F., AND L. RAHM. 1988. Long-term, seasonal and spatial variations of nitrogen, phosphorus and silicate in the Baltic: An overview. Mar. Environ. Res. 26: 19-37.

— - AND 1989. Optimizing the Baltic sampling programme: The effects of using different stations in calculations of total amount of nutrients. Beitr. Meereskd. Berl. 60: 61-66.

YoshinARI, T., AND R. KNowles. 1976. Acetylene inhibition of nitrous oxide reduction by denitrifying bacteria. Biochem. Biophys. Res. Comm. 69: 705-710.

ZimmermanN, R., R. IturRiaga, AND I. BeCKER-BIRCK. 1978. Simultaneous determination of the total number of aquatic bacteria and the number thereof involved in respiration. Appl. Environ. Microbiol. 36: 926-935.

Submitted: 15 August 1991 Accepted: 14 April 1992 Revised: 20 May 1992 